\title{
DESTINATION CHOICE IN GERMAN WINTER SPORT TOURISM: EMPIRICAL FINDINGS
}

\author{
ALEXANDER HODECK, GREGOR HOVEMANN \\ Leipzig University, Faculty of Sport Science, Department of Sport Psychology and Sport Pedagogy \\ Mailing address: Alexander Hodeck, Leipzig University, Faculty of Sport Science, Department of Sport \\ Psychology and Sport Pedagogy, 59 Jahnallee Street, 04109 Leipzig, Germany, \\ tel.: + 4934 19731797, fax: + 4934 19731819, e-mail: hodeck@uni-leipzig.de
}

\begin{abstract}
Introduction. Despite the fact that sport tourism plays an important role in upland destinations, as a field of research it is still characterised by a knowledge deficit. Material and methods. Active winter sport tourists at two upland destinations were compared in terms of socio-demographic variables, the importance of destination choice criteria, and travel behaviour in order to give recommendations to destination management organisations. Conclusions. There were significant differences between tourists at the two destinations. Consequently, advantages may be gained from the development of destination-specific marketing strategies.
\end{abstract}

Key words: winter sport tourism; upland destinations; destination choice

\section{Introduction}

Over the last few decades, sport tourism has gained more and more economic importance. This is why it has become an interesting topic for researchers. Nonetheless, the field is still characterised by a knowledge deficit [1]. While some scientists focus on defining a theoretical framework [2], others work more empirically. The term sport tourism may sometimes be replaced by other notions such as adventure tourism or sporty tourism or more specific terms for a particular branch (e.g. ski tourism). In this paper, however, the term sport tourism shall be used in its broad definition [2]. Due to the heterogeneity of sport tourists and the uniqueness of destinations, a comparison of the results of different studies is almost impossible [3]. As competition between service providers in sport tourism has also increased, not only theorists but also practitioners are interested in new findings in this field. Sport has moved to one of the seven top motivating factors for German tourists [4]. In Germany, uplands are traditional sport tourism destinations. In these regions in particular winter sport tourism plays an important role [5]. When it comes to the literature on this topic, it can be stated that a number of studies have already discussed winter sport tourism. Most of them, however, concentrate on mountains with peaks at an altitude of over 2000 metres [6, 7, 8, 9, 10]. Not much research has been carried out regarding winter sport tourism in uplands (peaks between 500 and 2000 metres). Furthermore, the changing competitive situation in the tourism industry seems to be especially challenging for uplands [11], owing to changes in climate [12] and demographics [13]. It is therefore obvious that these destinations in particular must develop new marketing strategies. The main objective of this study is to investigate whether active winter sport tourists travelling to different upland destinations are comparable regarding their socio-demographic data, destination choice criteria, and actual travel behaviour. Additionally, the results of this paper will be a helpful source of information for destination management organisations wanting to develop future marketing strategies. The two destinations that this study focuses on are the Ore Mountains (Erzgebirge) and the Black Forest (Schwarzwald). The two desti- nations are similar in terms of topography, the services offered (Alpine as well as cross-country skiing), and their traditional status as winter sport destinations. The Ore Mountains are situated in the southeast and the Black Forest Mountains in the southwest of Germany. The hypothesis to be proven by this study is: There are no significant differences between active winter sport tourists of the upland destinations investigated regarding socio-demographic variables and the importance of destination choice criteria in the destination choice process.

\section{Destination choice in sport tourism}

In the field of sport tourism different models of the destination choice process can be applied [14, 15, 16]. These models relate to micro-economic theories and to behavioral theory. For this study the destination choice process by Pearce [16] was used, adapted to different sport destinations in one country by Konu et al. [3]. According to the results of the above-mentioned studies, internal as well as external factors influence the destination choice process. Internal factors refer to the personal characteristics or motives of tourists and external factors to characteristics or images of a set of destinations to be chosen. In terms of the destination choice process of active sport tourists, the available information is still insufficient. Only a few studies have been carried out on this topic [3,11, 14]. Klenosky, Gengler and Mulvey [14] applied the means-end approach. According to this study, variety and the challenging character of the hills and trails meet the tourists' desire for fun and action. Factor analysis was used by Konu et al. [3] in order to determine which aspects are important for tourists' choice of a winter sport destination. This led to the identification of four factors: Alpine skiing services, Nordic skiing services, restaurant variety, and additional services related to social life such as SPA and Wellness offers. Based on these four factors, six segments of winter sport tourists were defined. Even though winter sport tourism is an important economic factor in uplands, only one study has ana-lysed the features of winter sport tourists visiting uplands so far $[11,17,18]$. There is only one study dealing with destination choice in a German upland. Hodeck and Hovemann [11] analysed winter sport tourists in the Erzgebirge (Ore Moun- 
tains). They extracted four factors (Nordic skiing, Alpine skiing, additional services, and specific destination characteristics) from 15 destination choice criteria. Based on those factors, six groups of active winter sport tourists could be clustered.

\section{Material and methods}

The data $(n=450)$ were collected in two German uplands (Ore Mountains and Black Forest) during the 2013/2014 winter season. The sample was selected using a multistep process, and the cluster sampling (or area sampling) method was chosen [19]. In each destination the data were collected during four different time frames of the 2013/14 winter season (once during the Christmas holidays, once at the weekend in January and twice during the German winter holidays). The subjects were randomly selected. Specially trained interviewers, who were all students of sport management programmes, used a standardised questionnaire for the interviews and collected the data in relevant sport tourism places. A similar selection process had already been used in another study [11]. The data were always collected at five different locations: ski slopes (2), ski tracks (2) and hotels (1) (cf. tab. 1).

Table 1. General characteristics of the sample

\begin{tabular}{|l|l|}
\hline N & 450 \\
\hline Gender & Female: $45.6 \% ;$ Male: $54.4 \%$ \\
\hline Average age & 38.49 years \\
\hline Destination & Ore Mountains: $49.8 \%$; Black Forest: $50.2 \%$ \\
\hline
\end{tabular}

The winter sport tourists staying at the two destinations were compared in terms of socio-demographic variables and travel behaviour. Differences between the active sport tourists were analysed by cross-tabulation (nominal data) and t-test (metric data). The data were analysed for normal distribution and homogeneity of variances before significance was tested. Afterwards the t-test or the Welch test was applied. These tests were chosen as the distribution of the data was normal regarding the variables analysed, and the differences in the number of tourists interviewed in both destinations seemed to be acceptable. In order to evaluate the importance of the factors extracted from the destination choice process, 14 different destination choice criteria from existing studies $[3,11]$ were used in a factor analysis with varimax rotation. The same method has been applied by Konu et al. [3] and by Hodeck and Hovemann [11]; the results of these studies can thus be compared with the findings presented in this paper.

\section{Results}

First of all, the active sport tourists visiting the two destinations who were interviewed were compared in terms of sociodemographic data. There was no significant correlation (Pearson's Chi-Square: $0.102, \mathrm{p}>0.1$ ) between gender and the destination chosen. However, the tourists in the Ore Mountains and those in the Black Forest showed significant differences regarding their age: the individuals visiting the Ore Mountains were on average six years older than the tourists in the Black Forest (cf. tab. 2).
Table 2. Gender of the active winter sport tourists interviewed (observed and expected figures)

\begin{tabular}{|c|c|c|c|}
\hline & & \multicolumn{2}{|c|}{ Destination } \\
\hline & & Ore Mountains & Black Forest \\
\hline \multirow{2}{*}{ Gender } & Female & $123(121.3)$ & $80(81.7)$ \\
\hline & Male & 146 (147.7) & $101(99.3)$ \\
\hline
\end{tabular}

Furthermore, significant differences between the active winter sport tourists staying at the two destinations were found re garding the distance they travelled to reach the destinations and the duration of their stay (cf. tab. 3).

Table 3. Average differences in age, distance travelled, and length of stay for the active winter sport tourists interviewed

\begin{tabular}{|l|c|c|c|c|}
\hline & Ore Mountains & Black Forest & $\mathrm{t}$ value & Significance \\
\hline Age (mean) & 40.72 & 34.23 & 4.36 & $\mathrm{p}<0.001$ \\
\hline Distance travelled (km) & 98.59 & 278.15 & 4.93 & $\mathrm{p}<0.001$ \\
\hline Length of stay (days) & 1.89 & 5.25 & 3.51 & $\mathrm{p}<0.001$ \\
\hline
\end{tabular}

When it comes to actual travelling behaviour, the active winter sport tourists in the Black Forest clearly did not only spend more time in this region. They also spent significantly more money per day. The average active sport tourist in the Ore Mountains spent $57.54 €$ per day at their chosen destination, while a tourist in the Black Forest spent 137.82€ per day on average. This difference becomes even more apparent after calculating how much money was spent during the entire stay (expenditure per day multiplied by the number of days). The sport tourists visiting the Black Forest interviewed spent almost seven times as much money during their stay (723.56€) as those in the Ore Mountains (108.75€) (cf. tab. 4).

Table 4. Average differences in expenditures per day for the active winter sport tourists interviewed

\begin{tabular}{|l|c|c|c|c|}
\hline & $\begin{array}{c}\text { Ore } \\
\text { Mountains }\end{array}$ & $\begin{array}{c}\text { Black } \\
\text { Forest }\end{array}$ & t value & Significance \\
\hline $\begin{array}{l}\text { expenditures } \\
\text { for drinks / meals (€) }\end{array}$ & 20.03 & 37.92 & 7.73 & $\mathrm{p}<0.001$ \\
\hline $\begin{array}{l}\text { expenditures } \\
\text { for sleeping (€) }\end{array}$ & 19.36 & 40.45 & 5.82 & $\mathrm{p}<0.001$ \\
\hline $\begin{array}{l}\text { expenditures } \\
\text { for sporting activities }(€)\end{array}$ & 12.91 & 39.88 & 10.17 & $\mathrm{p}<0.001$ \\
\hline $\begin{array}{l}\text { expenditures } \\
\text { for other activities }(€)\end{array}$ & 5.24 & 19.57 & 3.85 & $\mathrm{p}<0.001$ \\
\hline
\end{tabular}

With regard to destination choice criteria, the data seemed to be suitable for a factor analysis (KMO-Criteria: 0.831). This was also confirmed by a Chi-square value of 3650.96 ( $p<0.001)$. Four factors explaining 71.1 per cent of the variance were extracted. These factors can be described as "cross-country skiing", "Alpine skiing", "additional services", and "basic characteristics".

The final question was whether active sport tourists visiting the two destinations rated the importance of the above-mentioned factors differently in the destination choice process. As could have been expected, the tourists who had chosen the Ore Mountains were more interested in cross-country skiing than those in the Black Forest, who seemed to consider Alpine skiing more interesting (cf. tab. 5). 
Table 5. Results of the factor analysis

\begin{tabular}{|l|c|c|c|c|}
\hline & $\begin{array}{c}1 \\
\text { Cross- } \\
\text { country } \\
\text { skiing }\end{array}$ & $\begin{array}{c}2 \\
\text { Alpine } \\
\text { skiing }\end{array}$ & $\begin{array}{c}3 \\
\text { Additional } \\
\text { services }\end{array}$ & $\begin{array}{c}4 \\
\text { Basic } \\
\text { character- } \\
\text { istics }\end{array}$ \\
\hline Quality of ski tracks & 0.947 & & & \\
\hline Variety of ski tracks & 0.951 & & & \\
\hline Number of ski track kilometres & 0.937 & & & \\
\hline Multi-destination ski tracks & 0.829 & & & \\
\hline Variety of ski slopes & & 0.910 & & \\
\hline Number of ski slopes & & 0.901 & & \\
\hline Length of ski slopes & & 0.894 & & \\
\hline Variety of restaurants & & & 0.803 & \\
\hline Active nightlife & & & 0.756 & \\
\hline Spa- \& Wellness-Services & & & 0.641 & \\
\hline Value for money & & & & 0.689 \\
\hline Short distance from home & & & & 0.600 \\
\hline Snow conditions & & & & 0.568 \\
\hline Family friendly services & & & & 0.549 \\
\hline $\begin{array}{l}\text { KMO measure of sampling adequacy } 0.831 / \mathrm{p}<0.001 / \\
\text { Cumulative percentage of variance explained: } 71.1\end{array}$ \\
\hline
\end{tabular}

Additional services and the basic characteristics of the des tination were more important to the active sport tourists in the Ore Mountains. Snow conditions and value for money were the top destination choice characteristics in general. Good snow conditions were the basis for every kind of active winter sport tourism. It is worth emphasising that the "price" factor has been defined as very important in almost every study dealing with (sport) tourism (cf. tab. 6).

Table 6. Average differences in the importance of destination choice criteria for the active winter sport tourists interviewed

\begin{tabular}{|l|c|c|c|c|}
\hline & Ore Mountains & Black Forest & $\mathrm{t}$ value & Significance \\
\hline Cross-country skiing & 1.70 & 0.73 & 7.73 & $\mathrm{p}<0.001$ \\
\hline Alpine skiing & 2.09 & 2.45 & 3.16 & $\mathrm{p}<0.05$ \\
\hline Additional services & 1.79 & 1.20 & 6.13 & $\mathrm{p}<0.001$ \\
\hline Basic characteristics & 3.14 & 2.67 & 6.30 & $\mathrm{p}<0.001$ \\
\hline
\end{tabular}

0 - not important at all; 4 - very important.

\section{Discussion}

Regarding the destination choice criteria, the factor analysis helped identify four factors, which are similar to those in existing research focusing on German uplands [11] or upland destinations in the north of Europe [3]. However, the results of these studies differ from those dealing with destinations in mountains with peaks at an altitude of over 2000 metres [6, 7, 9]. Only in some uplands (such as the Ore Mountains) does cross-country skiing seem to be important for active winter sport tourists, while Alpine skiing is preferred by winter sport tourists in high mountains $[3,6]$ as well as in uplands. There are significant differences between several upland destinations. This study showed that while the Black Forest Mountains attracted tourists especially interested in Alpine skiing, the Ore Mountains were primarily attractive for those interested in cross-country skiing. It must be mentioned that some results of this investigation do not correspond with the findings of Hodeck and Hovemann [11]. These differences may stem from the different environmental condi- tions (weather and snow) during the time when data were collected. Upland destinations in general attract tourists living between 120 and 275 kilometres away. This is less than the distance travelled by tourists visiting high mountains [6].

There are significant differences regarding socio-demographic variables, travel behaviour, and destination choice criteria between active sport tourists travelling to different upland destinations. Due to some destination-specific peculiarities, the features of active sport tourists visiting different upland destinations cannot be generalised. It is very surprising that the active winter sport tourists interviewed at both destinations differed significantly regarding their tourist behaviour, despite the fact that the two destinations are very similar in topography and the services offered. It can only be hypothesised why the Black Forest Mountains attracted especially Alpine skiers and the Ore Mountains were chosen by cross-country skiers: this might have been due to the development of sport tourism in these destinations, actual marketing strategies, or both. More research should be done to explain these differences. Further studies should also be carried out in order to help destination management organisations develop future destination-specific marketing strategies. The results of this research should be discussed critically, as they cannot be seen as representative for sport tourism at the two chosen destinations in general. Only data collected during one season was described. In addition, only tourists who had already chosen their destination were interviewed, thus the study did not determine whether tourists who did not choose this destination were different from those who did choose it. As a consequence, this study can only give first ideas for the development of new strategies. Its results should be confirmed by further studies carried out during different seasons and in other destinations. However, one preliminary conclusion is that Alpine skiers seem to be a more attractive target group for winter sport destinations than cross-country skiers. More research should be done regarding the differences between summer and winter sport tourists, as the development of destinations should not be reduced to the winter season only. In upland destinations in particular it is necessary to introduce year-round strategies to counter the effects of global warming.

\section{Conclusions}

The aim of this research was achieved, although this study has some limitations. The initial hypothesis must be rejected due to significant differences between active winter sport tourists visiting to the two destinations investigated. The main findings of the research can be summarised as follows:

1. There were significant differences between active winter sport tourists in different upland destinations regarding socio-demographic variables and tourist behaviour.

2. There were significant differences between active winter sport tourists of different upland destinations regarding the significance of destination choice criteria in the destination choice process.

3. It is necessary to develop destination-specific marketing strategies for upland sport destinations.

\section{Literature}

1. Schwark J. (2007). Sport tourism: introduction and overview. European Journal of Sport and Society 4(2), 117-132.

2. Schwark J. (2006). Basics of Sport Tourism. Münster, Germany: Waxmann. [in German]

3. Konu H., Laukkanen T., Komppula R. (2011). Using ski destination choice criteria to segment Finnish ski resort customers. Tourism Management 32, 1096-1105. 
4. Aderhold P. (2011). Travel Behaviour of Germans. Short version of the German Travel Analysis 2011. Kiel, Germany: FUR. [in German]

5. Ronge C. (2012). Development of tourism in Saxony 19922011. Kamenz, Germany: Statistisches Landesamt. [in German]

6. Dolnicar S., Leisch F. (2003). Winter tourist segments in Austria: identifying stable vacation styles using bagged clustering techniques. Journal of Travel Research 41(3), 281-292.

7. Perdue R. (2004). Sustainable tourism and stakeholder groups: a case study of Colorado ski resort communities. In G. Crouch, R. Perdue, H. Timmermanns, M. Uysal (eds.), Consumer psychology of tourism, hospitality and leisure (pp. 253-264). Wallingford: CABI Publishing.

8. Füller J., Matzler K. (2008). Customer delight and market segmentation: an application of the three-factor theory of customer satisfaction on life style groups. Tourism Management 29(1), 116-126.

9. Won D., Bang H., Shonk D. (2008). Relative importance of factors involved in choosing a regional ski destination: Influence of consumption situation and recreation specialization. Journal of Sport and Tourism 13(4), 249-271.

10. Hallmann K., Zehrer A., Müller S. (2013). Perceived destination image: An image model for winter sports destination and its effect on intention to revisit. Journal of Travel Research, 1-13. DOI: 10.1177/0047287513513161

11. Hodeck A., Hovemann G. (2013). Typification of winter sport tourists in German highlands. Sciamus 4(4), 1-13. [in German]

12. Landauer M., Pröbstl U., Haider W. (2012). Managing crosscountry skiing destinations under the conditions of climate change - Scenarios for destinations in Austria and Finland. Tourism Management 33, 741-751.
13. Grimm B., Metzler D., Butzmann E., Schmücker D. (2010). Impact of demographic changes on demand in Germany and selected markets. Future travel market and behaviour of different age groups. Tw Zeitschrift für Tourismuswirtschaft 2(2), 111-132. [in German]

14. Klenosky D., Gengler C., Mulvey M. (1993). Understanding the factors influencing ski destination choice: A means-end analytic approach. Journal of Leisure Research 25(4), 362379.

15. Papatheodorou A. (2001). Why people travel to different places. Annals of Tourism Research 28(1), 164-179.

16. Pearce P. (2005). Tourist behavior: Themes and conceptual schemes. Clevedon, UK: Channel View.

17. Tsiotsou R. (2006). Using visit frequency to segment ski resorts customers. Journal of Vacation Marketing 12(1), 15-26.

18. Vassiliadis C., Priporas C.V., Andronikidis A. (2012). An analysis of visitor behavior using time blocks: A study of ski destinations in Greece. Tourism Management 34, 61-70. DOI: 10. 1016/ j.tour-man.2012.03.013.

19. Berekoven L., Eckert W., Ellenrieder P. (2001). Market research. Methodical basics and practical application. Wiesbaden, Germany: Gabler. [in German]

Submitted: October 1, 2014

Accepted: June 22, 2015 